\title{
STUDIES ON THE RESPIRATION OF INSECTS.
}

\section{The Gases and Respiratory Proteins of Insect Blood.}

Richard A. Muttkowski, Ph. D.

(Contribution from the Zoological Laboratory of the University of Idaho, Moscow, Idaho).

2. Oxygen and Respiratory Proteins in Insect B1ood.

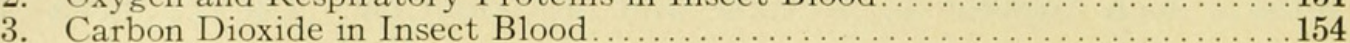

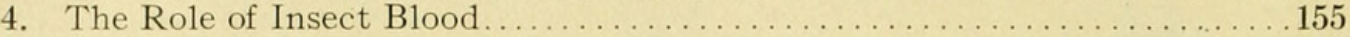

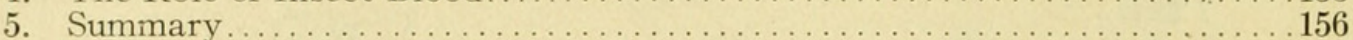

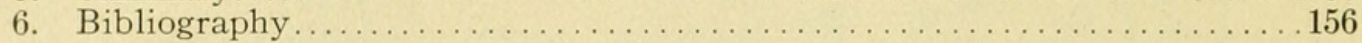

\section{INTROLUCTORY.}

The following paper aims to present certain phases of investigations on the respiration, of insects. In a recent article (see Bull. Brooklyn Ent. Soc., 15, pp. 89-96, 131-140) I called attention to the fixation of oxygen by the blood of some aquatic insects. "In a few rare cases," it was stated (p. 94), "the carrier is colored. Thus, in some species of Chironomidæ, the pigment is hemoglobin, like that of Vertebrates, except that it is found in the plasma, not within the corpuscles. *** The oxygen diffuses through the epidermis just as in the case of vertebrates, and is fixed by the hemoglobin or other carrier (perhaps hemocyanin?) in the blood. Just what this other carrier may be is not definitely ascertained. But by far the larger number of aquatic insects have no visible colored carrier or respiratory pigment. Thus, for example, Trichoptera larvæ, the larvæ of Simulium, of Culicidæ, and of most Chironomidæ, have gill pouches, usually placed at the caudal end, but all without any visible indication of a respiratory pigment."

As at present understood, respiration among Tracheates proceeds directly; atmospheric oxygen is led directly to the cells by the tracheae, while the blood acts primarily in the transportation of food and metabolic products. The question whether or not the blood may play a certain part in the transportation of gases is a point that merits investigation.

The following experiments on this subject were performed during spring, summer and fall of 1920, although some earlier observations are included in this paper. 


\section{Oxygen and Respiratory Proteins in Insect Blood.}

To determine the oxygen content of insect blood directly is a matter of some difficulty, primarily because such reagents as are available are suitable only for considerable quantities of material, and are not adaptable for use with the microscopic quantities dealt with in the present experiments. For instance, an excellent reagent is pyrogallic acid, which in presence of an alkali absorbs oxygen with avidity. When testing for oxygen in the few drops of blood obtained from an insect, the difficulty lay in occluding atmospheric oxygen. Yet several experiments indicated the presence of oxygen in the blood; for the reagent darkened much more rapidly when applied to insect blood (pyrogallic acid turns brown to black with absorbed oxygen) than in the blank control tests. Yet at best this was unsatisfactory, as at least some portion of the reagent was in contact with atmospheric oxygen and tended to obscure the blood reaction. Nor could this be obviated with the use of cell slides and vaselined cover slips.

However, the same reagent was applied to Dytiscus larvæ by another method which was more effective. Freshly prepared pyrogallic acid solution was injected into the body cavity of the larvæ, followed by weak hydroxide. Death ensued quickly, in periods ranging from ten seconds to three minutes. Even before dissection the semi-transparent larvæ showed brown stains inside. The dissected larvæ showed brown blotches in the haemocoel and among the tissues, indicating that oxygen had been absorbed by the reagent. In the vicinity of the tracheæ the reagent was deeper brown, while the tracheæ themselves were almost black. Here, too, once the animal was cut open, atmospheric air had access to the reagent, which then blackened rapidly, obscured the tissues, and prevented more detailed study.

No doubt some of this reaction was due to oxygen dissolved in the blood serum, although the serum has no power to combine with oxygen like a respiratory protein. This oxygen, in mammalian serum, amounts to $94 \%$ of the amount soluble in water and the serum loses its supply with increased temperature.

These experiments, which were repeated a number of times with Dytiscus, Aeshna, Chironomus, and other larvæ, are significant from at least the qualitative standpoint. They do not indicate whether an active agent was present which combined loosely with the oxygen, or if the gas was in physical solution as in the water. The topic was, therefore broached from another angle - namely, that of the presence or absence of respiratory proteins. The obvious postulate was: If a respiratory pigment can be demonstrated in the blood of insects, its purpose must be to fix and transport oxygen. In that case, the blood of insects has the additional function of aiding in the respiration.

Such a respiratory protein need not necessarily be visible to the naked eye. For, in the first place, among the insects we are dealing with minute quantities of blood. Secondly, such a pigment wculd play only a subsidiary role, as the primary supply of oxygen is received by way of the tracheæ. The quantities of gas in solution in the blood 
would, therefore, be minimal. Besides, even in such animals as crayfish, where the respiratory protein is known to be hemscyanin and bluish in color, when fully oxidized, the blood generally shows no color at all. It may be entirely transparent, or a pale to definite blue. Or it might be a pink to bright red, depending upon the amount of non-respiratory pigment (Tetronerythrin) present. In insects the blood, if colored at all, is bluish or greenish, forming black clots. There are exceptions to this, such as adult Dytiscus, in which the blood is saffron yellow to orange in color, although blue to purple in the larvæ. This color is not due to any respiratory protein, but to non-respiratory pigments, which are stored in the blood and elaborated into the external colors of the adult.

Assuming a respiratory pigment for the moment, there are two possibilities - the carrier in question may be either hemoglobin, or hemocyanin, or both, as in some mollusks. As far as known to the writer, hemocyanin has not been definitely reported for insects, while hemoglobin is known only for the Chironomid "blood-worms."

A considerable number of experiments were performed in the ensuing investigations. These experiments on respiratory proteins in insects have been described elsewhere, but since they bear on this discussion, a summary of the salient points will be necessary.

The problem as studied, presented the following phases: Considering that conditions as met in aquatic insects postulate the presence of a respiratory protein, can such a protein be demonstrated? (2) If present, what is its nature? (3) Is it confined to aquatic insects possessing blood gills, or is it universal among insects?

For the first of these it was shown that the blood of insects reacts with the oxidation tests for hemoglobin (Guiac, O-tolidin, Benzidine), regardless of the species. Only Chironomid blood reacted with the hemin tests for hemoglobin. These tests showed that a respiratory protein was present.

In the second phase, considering the nature of this protein, two possibilities offered themselves. Of known proteins in Arthropoda there are only hemocyanin and hemoglobin. The first of these has a copper nucleus, the second is an iron compound. The hemin tests for hemoglobin showed that this protein is restricted to Chironomid "bloodworms" among the insects. It is a fact, however, that the blood of Aeshna, Anax, Dytiscus, and other insects showed isolated crystals resembling the hemin prisms. If present at all, therefore, hemoglobin is available only in infinitesimal quantities and may be disregarded.

For hemocyanin no direct tests are known. It was held, however, that if by some means copper could be shown to be present in insect blood in quantities as large as found in crayfish blood where the copper has a known function, then its role in both is identical. For this purpose a number of incinerations of insect and crayfish blood were made and the ashes tested for copper. Both reacted positively, showing copper in approximately equal amounts. It was therefore concluded that insects contain a respiratory of a nature similar to that of the crayfish, namely a hemocyanin. 
In the third phases of that study, the distribution of copper in insects, the following list of animals were incinerated. (Numbers refer to number of separate incinerations, not to number of specimens):

Coleoptera: Dytiscus, 19; Gyrinus, 1; Harpalus, 1; Leptinotarsa, 1.

Hymenoptera: Apis, 2; Bombus, 1; Polistes, 2; Formica, 1.

Lepidoptera: Pieris, 4; Noctuidæ, 2.

Diptera: Musca, 4; Stomoxys, 2; Tachinid, 1; Stratiomyia, 1.

Hemiptera: Belostoma, 17; Ranatra, 1; Notonecta, 3; Gerris, 1; Corixa, 2; Aphis, 1 , Leptocoris, 2.

Odonata: Anax and Aeshna, 4; Anax, 2; Aeshna, 15; Sympetrum, 4; Libellula, 4; Enallagma, 6.

Ephemeridæ: Several spp., 1.

Trichoptera: Several spp., 1.

Neuroptera: Myrmeleon, 3 .

Megaloptera: Sialis, 1.

Isoptera: Termes, 1.

Orthoptera: Gryllus, 1; Ceuthophilus, 1; Locusta, 1; Melanoplus, 1; Dissosteira, 1.

Crustacea: Cambarus, 36; Hyalella, 2; Plankton, 1; Daphnia, 2; Microcystis, 1; Limnocalanus, 1.

Arachnida: Argiope, 1; Phaleana, 1; Spiders, 1.

Myriapoda: Centipeds, 1 ; millipeds, 1.

Annulata: Lumbricus, 1.

Mollusca: Snails, 5; slugs, 2.

Nemathelminthes: Ascaris, 1.

Protozoa: Volvox, 1.

Chordata: Snake blood, 1; human blood, 1; mouse, 1.

All of these, except human blood, reacted positively for copper, showing varying amounts.

As a final phase, the sources of copper were studied. Some 30 incinerations were made of twelve species of plants, all of which showed traces of copper. The soil and water were also tested, with positive results.

All of the Arthropoda studied showed a surprising uniformity in their reactions for copper. In practically all cases copper was present in quantities nearly equal to that of crayfish blood. This uniformity must have its significance. Copper in the quantities found could not come to the insects in their daily feeding, unless the tissues exercised a discriminating selection for the copper in their food. This copper must be functional, and because of the analogies pointed out it is interpreted as forming the nucleus of a respiratory protein, hemocyanin.

There is a further point to be considered. Unless we assume a blood protein to fix the oxygen, we cannot account for the presence of oxygen in the blood of insects living under practically anaerobic conditions, that is, insects living in warm and stagnant water.

Physically, oxygen tends to form a balance on both sides of a moist or immersed membrane. But since in the summer there are two factors which tend to decrease the oxygen supply available to insects in the water, namely organic decomposition and the heat of the water, the amount of oxygen, on a purely physical basis, would diminish also within the insect. Water contains its largest amount of dissolved oxygen at zero, and as the temperature rises this amount becomes less 
and less, until it is zero at boiling point of the water. Furthermore, as the temperature of water rises above zero, decomposition and oxidation of wastes increase, so that the available supply of dissolved oxygen is used up in inverse ratio to its absorption by the water.

If respiration in aquatic insects, specifically in water-breathers, proceeded on the basis of a physical gas equilibrium on two sides of a membrane, the insect would soon show a deficiency of oxygen, and that at a time when it is most active and its metabolism demands a high rate of oxygenation. Yet this is precisely what we do not find. Regardless of the impoverished oxygen in warm pond or swamp water, the insect blood contains a plentiful supply of oxygen, and metabolism proceeds at its normal rate. Thus, in Aeshna, Dytiscus, and Chironomid larvæ, purposely kept in covered jars filled with decaying plant and animal matter, I found normal activity and the blood reacted copiously with injections of Pyrogallic acid. It is evident, therefore, that the blood possesses a protein which is capable of binding oxygen in excess of the amounts dissolved in the water. The incinerations showed that this protein is a copper compound.

From this standpoint, the various respiratory structures of insects, especially the gill filaments and gill pouches of Trichoptera larvæ and aquatic caterpillars, the caudal blood gills of Chironomus larvæ, of Culicid larvæ, Simulium larvæ, etc., acquire a real significance. These structures are purely blood gills, consisting of a thin cuticle and epidermis and their lumina are continuous with the haemocoel, so that the blood courses freely through them. With this type of gill, a respiratory protein to fix oxygen is very effective. On the other hand, unless such a protein is present, these structures loose their significance, in fact, appear useless as organs and inefficient physiologically.

\section{Carbon Dioxide in Insect Blood.}

The presence of carbon dioxide in insect blood has been reported frequently. During the summer of 1920 I was able to verify this fact in several series of experiments. The insects used were the same species utilized in the incinerations listed in the preceding section. The reagents employed were Potassium and Barium hydroxides, Lead acetate, Rosolic Acid, and halogen acids, the latter for carbonates. Of these Potassium hydroxide was perhaps the least satisfactory, as it is difficult to find the proper concentration of this reagent to give a definite reaction. Barium hydroxide reacts well with insect blood, yielding an amorphous precipitate. Lead acetate when applied directly will precipitate some of the blood proteins in addition to the carbon dioxide. When used with a micro-still, however, it is more effective and conclusive. I have used it as follows: A few drops of insect blood are caught on glass wool in a small glass or porcelain crucible, over which is placed a slide with a hanging drop of Lead acetate. Gentle heating releases the carbon dioxide, which forms Lead carbonate with the reagent. 
As in the incinerations of insects for copper, crayfish blood was used as a control, with identical results. It seems then that in the latter the hemocyanin serves as a carrier for both oxygen and carbon dioxide, analogous to hemoglobin; and the presumption is that the same applies to insect blood.

Among other items, the Malpighian tubules of insects were studied as a possible exit for Carbon dioxide and carbonates. A number of experiments were made with the reagents mentioned on a variety of tubules, including those of bumblebees, larval and adult Dytiscus, Anax and Aeshna larvæ, Belostoma, Enallagma, and others. In summary, ten of eighty-one experiments showed positive results, the remaining seventy-one negative or doubtful. Even with a liberal allowance for error, these results are too insufficient to permit of any conclusions.

Elsewhere I have offered the suggestion (L. c., p. 93) that at least in aquatic larvæ the external chitin membrane may serve for the passage of carbon dioxide. This suggestion was based on some experiments on the permeability of the chitin membrane to gases, performed some years ago. However, this might apply to aquatic insects, it would not cover the conditions met in terrestrial stages.

\section{The Role of Insect Blood.}

Hitherto our interpretation of the role of insect blood has been that the blood transports food, glandular products, waste, and pigments, and that it takes no part in the process of respiration. From the foregoing experiments it is evident that this interpretation must be amended to include respiration.

That the blood is active in transporting foods can be readily shown in testing fed and starved insects. After a meal the blood shows a large supply of nitrates, nitrites, and phosphates, the latter depending on the quality of food, whether rich or poor in phosphates. In a starved specimen, not fed for three or more days, none or only traces of these substances are indicated.

Glandular products include corpuscles, enzymes, some form of coagulin, and pigments. The pigments are carried passively in the blood stream, to be elaborated during the pupal period. The enzymes present are chiefly of the oxidative, histolytic, and autolytic types. Here also should be placed hemocyanin and hemoglobin, the respiratory proteins. In what tissues or organs these are elaborated has not been ascertained. Coagulin in some form must also be present, as the blood of insects clots readily on exposure to atmospheric air. This clot is generally black, but brown in adult Dytiscus. Whether this coagulin originates as a zymogen of the prothrombin type, forming thrombin, and combining with fibrinogen to form fibrin, as postulated for mammalian blood, is unknown.

Of gases the blood contains both oxygen and carbon dioxide, some probably dissolved in the blood serum, the major portion held by the hemocyanin present. 
On this basis, the role of insect blood may be summarized as follows: The blood is instrumental (1) in circulating food, (2) transporting metabolic products (enzymes, pigments, etc.), (3) in respiration in the distribution of oxygen and removal of carbon dioxide.

Be it noted that the last of these, the role in respiration, is not confined to aquatic larvæ alone - that is, larvæ provided with blood gills. On the contrary, the role of the blood is identical in all insects, regardless of the stage. For the tests for respiratory proteins (oxidation and incineration) were performed on all types of insects, regardless of habitat, stage, and food habit of the species.

\section{SumMary.}

1. Both oxygen and carbon dioxide are present in insect blood. A small portion of these gases is probably dissolved in the blood serum, the major portion is held by a respiratory protein.

2. A respiratory protein was demonstrated for all insects through reactions with oxidation tests for hemoglobin. Hemoglobin is possessed exclusively by Chironomid "blood-worms" among insects. All other insects show the presence of copper, which is interpreted as forming the nucleus of another respiratory pigment, hemocyanin.

3. This hemocyanin is possessed by all insects, regardless of stage, habitat, or food. The source of this copper was shown to be the water, soil, and food plants.

4. The role of insect blood is therefore, in addition to its recognized function of circulating food and metabolic products, to aid the tracheal system in the distribution of oxygen to the tissues and to remove the carbon dioxide.

\section{BIBLIOGRAPHY.}

Muttkowski, R. A. The Respiration of Aquatic Insects: A Collective Review. Bull. Brooklyn Ent. Soc., 15, pp. 89-96, 131-140, 1920.

Rose, W. C., and Bodansky, M. Biochemical Studies on Marine Organisms: I. Copper in Marine Organisms. Jn. Biol. Chem., 44, pp. 99-112, 1920. 


\section{$2 \mathrm{BHL}$ Biodiversity Heritage Library}

Muttkowski, R A. 1921. "Studies on the Respiration of Insects." Annals of the Entomological Society of America 14, 150-156.

https://doi.org/10.1093/aesa/14.2.150.

View This Item Online: $\underline{\text { https://www.biodiversitylibrary.org/item/43628 }}$

DOI: https://doi.org/10.1093/aesa/14.2.150

Permalink: https://www.biodiversitylibrary.org/partpdf/193541

\section{Holding Institution}

Smithsonian Libraries

\section{Sponsored by}

Smithsonian

\section{Copyright \& Reuse}

Copyright Status: NOT_IN_COPYRIGHT

This document was created from content at the Biodiversity Heritage Library, the world's largest open access digital library for biodiversity literature and archives. Visit BHL at https://www.biodiversitylibrary.org. 